\title{
GAMBARAN EFEKTIVITAS SEFTRIAKSON DAN SEFOTAKSIM PADA PASIEN DEMAM TIFOID USIA 5 - 19 TAHUN DI RSUD BEKASI PERIODE JANUARI 2019 -DESEMBER 2019
}

\author{
dr. Richard Yan Marvellini, Fenesa Tesalonika Bunga Ria Sagala \\ Fakultas Kedokteran Universitas Kristen Indonesia, Jakarta
}

Email : richardmarvellini@yahoo.com

\begin{abstract}
ABSTRAK
Demam tifoid merupakan infeksi usus halus yang disebabkan oleh bakteri Salmonella Typhi. Penyakit ini masih menjadi masalah kesehatan di Indonesia terkait dengan angka kejadiannya yang cukup tinggi. Cara penularan penyakit ini berhubungan dengan perilaku hidup bersih dan sehat dari masing-masing individu. Pengobatan demam tifoid menggunakan antibiotik dan telah ditemukan resistensi pada lini pertamanya yaitu kloramfenikol. Sehingga lini kedua yaitu seftriakson dan sefotaksim telah menjadi pilihan sebagai penggati dari lini pertamanya. Hal ini dikaitkan dengan efektivitasnya yang baik dalam mengobati pasien demam tifoid. Penelitian dilakukan dengan metode Content analysis yang dianalisis secara deskriptif retrospektif dengan menggunakan data sekunder yaitu rekam medis dari pasien RSUD Bekasi periode Januari 2019 - Desember 2019. Berdasarkan hasil penelitian mengenai waktu bebas panas dan lama perawatan didapatkan bahwa antibiotik seftriakson dan sefotaksim efektif dalam mengobati demam tifoid. Dilakukan uji kolerasi Mann Whitney $U$ dan didapatkan koefisien p 0,06 dan p 0,063 (p>0,05), sehingga dapat disimpulkan tidak terdapat perbedaan signifikan antara penggunaan antibiotik seftriakson dan sefotaksim. Kesimpulan yang dapat ditarik dari penelitian ini adalah seftriakson dan sefotaksim merupakan antibitoik yang efektif dalam mengobati demam tifoid.
\end{abstract}

Kata kunci : Demam Tifoid, Seftiakson, Sefotaksim, Salmonella typhi

\begin{abstract}
Typhoid fever is an intestinal infection caused by the bacterium Salmonella Typhi. However, this disease is still a health problem in Indonesia due to its high incidence. This disease's transmission is related to the clean and healthy lifestyle behavior of each individual. Treatment for the typhoid fever is antibiotic and resistance has been found in its first line, chloramphenicol. For the second line, ceftriaxone and cefotaxime, has become the choice as a substitute for the first line. This is associated with good effectiveness in treating typhoid fever patients. The research using content analysis method which is analyzed descriptively and retrospectively using medical records from RSUD on January 2019 - December 2019 period as the secondary data. Based on the results of research regarding heat-free time and length of treatment, it was found that the ceftriaxone and cefotaxime antibiotics were effective in treating typhoid fever. The Mann Whitney $U$ correlation test performed in this research and obtained a coefficient of $p 0.06$ and $p 0.063$ ( $p>0.05)$, which means that it can be concluded that there is no significant difference between the use of ceftriaxone and cefotaxime antibiotics. The conclusion that can be drawn from this study is ceftriaxone and cefotaxime are the effective antibiotics in treating typhoid fever.
\end{abstract}

Keywords : Typhoid Fever, Salmonella Typhi, ceftriaxone, cefotaxime 


\section{PENDAHULUAN}

Demam tifoid merupakan infeksi usus halus yang disebabkan oleh bakteri Salmonella typhi. Dimana, penyakit infeksi ini masih menjadi masalah kesehatan di Inedonesia terkait dengan insidennya yang tinggi. . Menurut WHO, insiden terjadinya demam tifoid berkisar 16 hingga 33 juta kasus per tahunnya dengan angka kematian mencapai 600 ribu per tahunnya. Demam tifoid merupakan penyakit rawat inap terbanyak ketiga di Indonesia dengan insiden mencapai 600.0001.500.000 kasus pertahunnya. Pada daerah pedalaman terdapat 760 kasus dari 10.000 populasi dan pada daerah kota 810 kasus dari 100.000 populasi per tahunnya. Secara keseluruhan, kasus demam tifoid cenderung meningkat dari tahun ke tahun dengan rata-rata angka kesakitan 500/100.000 penduduk dan angka kematian lebih dari 20.000 kasus. $^{1,2}$

Demam tifoid yang disebabkan oleh Salmonella typhi berhubungan erat dengan higienitas yang buruk sebagai penyebarannya melalui fecal-oral, biasanya ditemukan melalui makanan, minuman, dan sanitasi air yang buruk yang telah terkontaminasi. ${ }^{3}$ Di negara endemik sendiri termasuk Indonesia, insiden demam tifoid tertinggi pada usia 5-19 tahun. Hal ini dipengaruhi oleh kurangnya menjaga higienitas. Kebiasaan mengkonsumsi makanan dan minuman yang kurang terjaga higienitasnya dapat meningkatkan penyebaran bakteri Salmonella typhi. ${ }^{4}$

Dibutuhkan kurang lebih $10^{5}-10^{9}$ bakteri Salmonella typhi untuk menyebabkan penyakit demam tifoid. ${ }^{5}$ Tanda dan gejala yang ditimbulkan sangat bervariasi dan tidak spesifik. Gejala yang paling utama dirasakan adalah demam. Demam ini biasannya berlangsung kurang lebih 7 hari. Dengan pola demam biasanya meningkat pada sore hingga malam hari. Selain itu gejala yang biasa muncul pada minggu pertama biasanya sama seperti penyakit - penyakit infeksi lainnya. Seperti demam, nyeri kepala, mual, muntah, diare, dan rasa tidak enak diperut. ${ }^{6}$

Tatalaksana Demam tifoid meliputi terapi suportif, terapi simptomatik dengan tatalaksana utamanya adalah pemberian antibiotik. Tujuan tatalaksana dari demam tifoid adalah mengurangi angka kematian dan komplikasi dari pasien. Pengobatan yang Lini pertama dalam antibiotik pada demam tifoid adalah kloramfenikol. Namun, sudah banyak ditemukan kasus resistensi sehingga lini keduanya yaitu seftriakson dan sefotaksim banyak digunakan terkait dengan waktu bebas panas yang cepat, lama perawatan yang singkat, harga yang cukup terjangkau serta efek samping yang ditimbulkan sangat rendah. Seftriakson dan sefotak sim merupakan golongan sefalosporin generasi ketiga yang dimana kurang aktif terhadap bakteri Gram- positif dibandingan dengan generasi sebelumnya. Namun sangat efektif dalam membasu kuman dengan famili Enterobakteriaceae, termasuk strain penghasil penisilinase. ${ }^{7}$ Penelitian ini dilakukan untuk mengetahui efektivitas lini kedua pada pengobatan demam tifoid yaitu seftriakson dan sefotaksim di RSUD Bekasi.

\section{METODE PENELITIAN}

Penelitian ini merupakan penelitian deskriptif, menggunakan metode Content analysis ${ }^{8}$ pengumpulan data dilakukan secara retrospektif dengan menganalisis catatan rekaman medik pasien yang rawat inap di RSUD Bekasi periode Januari 2019 - Desember 2019. Penelitian ini bertujuan untuk mengetahui efektivitas seftriakson dan sefotaksin pada demam tifoid usia 5-19 tahun di RSUD Bekasi. Populasi target yang digunakan adalah Seluruh pasien demam tifoid usia 5 - 19 tahun periode Januari 2019 - Desember 2019 dengan sampel yang memenuhi kriteria inklusi dan tidak termasuk kriteria eksklusi. Teknik pengambilan sampel yang digunakan ada dengan consecutive sampling, yaitu melibatkan semua objek yang memenuhi kriteria inklusi.

Analisis data dilakukan dengan menganalisis karakteristik pasien meliputi jenis kelamin, usia, dan gejala yang dialami pasien. selanjutnya dilakukan analisis efektivitas penggunaan antibiotik terhadap waktu bebas panas, antibiotik yang digunakan, lama hari rawat inap pasien di rumah sakit Selanjutnya data di olah secara deskriptif yaitu data disajikan dengan apa adanya, jumlah masing-masing kelompok dihitung persentasenya terhadap jumlah keseluruhan.

\section{HASIL DAN PEMBAHASAN}

\section{Karakteristik pasien}

Pada penelitian ini didapatkan tersebut dapat disimpulkan pasien yang terkena demam tifoid yang berusia 5-19 tahun sebanyak 106 pasien di RSUD Bekasi. Dengan distribusi jumlah pasien laki - laki sebanyak 58 pasien dan wanita 48 pasien dengan presentase pasien laki-laki 54,7 persen dan pasien perempuan 45,3 persen. Dari sini, dapat disimpulkan bahwa pasien pria pada demam tifoid lebih banyak dari wanita. Walaupun belum terdapat penyebab pasti penyebab jumlah pasien pada pria lebih banyak dari 
pada wanita, terdapat beberapa faktor yang menyebabkan hal tersebut. Faktor - faktor tersebut adalah kebiasaan dalam menjaga kebersihan diri dan memilih makanan yang terjaga kualitas kebersihan. Hal ini sangat berpengaruh terkait dengan cara penyebarannya melalui makan. Penelitian yang dilakukan oleh Pramitasari pada tahun 2013 menyebutkan resiko kejadian demam tifoid pada pria,lebih tinggi 3,841 kali dibandingkan dengan perempuan. Peneliti menyebutkan faktor resiko yang berhubungan dengan kejadian tersebut adalah tingkat aktivitas pada laki-laki lebih tinggi dan makanan siap saji yang tidak terjamin meningkatkan resiko demam tifoid. ${ }^{9}$ Selain itu, penelitian yang dilakukan oleh Risha Fillah Fithria, Kiki Damayanti dan Risma Putri Fauziah juga mengatakan bahwa insiden demam tifioid dimana insiden pria lebih banyak dari pada wanita Personal hygiene sangat berpengaruh terhadap penyebaran bakteri Sallmonela typhi. ${ }^{10}$

Presentase penderita paling banyak terdapat pada kelompok usia 5-11 tahun dengan jumlah pasien sebanyak 64 pasien dimana memiliki presentase 60,3 persen. Lalu pasien dengan usia 12-16 tahun sebanyak 28 pasien dengan presentase 26,5 persen dan yang terakhir pasien dengan usia 17-19 tahun dnegan jumlah 14 pasien dengan presenrase 13,2 persen. Sesuai data yang terdapat diatas, dapat disimpulkan bahwa usia mempengaruhi angka kejadian dari demam tifoid. Penelitian yang dilakukan oleh Novie Homenta Rampengan menyebutkan bahwa di daerah endemis kasus demam tifoid tersering terjadi pada usia 5-19 tahun. ${ }^{11}$ Hal ini berkaitan dengan pengetahuan mengenai faktor-faktor yang dapat meningkatkan resiko terjadinya demam tifoid. Faktor - faktor yang mempengaruhi adalah kebiasaan jajan atau makan diluar rumah. Kebiasaan jajan atau makan diluar rumah dapat meningkatkan kejadian demam tifoid. Pengetahuan yang dimiliki pasien mengenai pentingnya menjaga kebersihan diri juga cukup berpengaruh. Penelitian yang disampaikan oleh Okky pramitasari mengatakan bahwa semakin tinggi usia seorang pasien tigkat mengenai kesadaran menjaga kebersihan diri semankin tinggi. Dengan ini dapat disimpulkan terdapat hubungan antara faktor usia dengan kejadia demam tifoid. Salah satu kebiasaan penting dalam menjaga higienitas diri adalah mencuci tangan sebelum dan sesudah makan. Penelitian yang dilakukan oleh Okky Purnia Pramitasari menyebutkan bahwa besar resiko terkena demam tifoid 6,769 kali lebih besar dari pasien yang tidak terbiasa mencuci tangan. Pencucian tangan dengan sabun dan pembilasan sesuai dengan langkah yang dianjurkan WHO akan menghilangkan miikroba yang terdapat pada tangan. ${ }^{12}$

gejala klinis pasien demam tifoid RSUD Bekasi
Tabel 1. Distribusi gejala klinis pasien demam tifoid RSUD Bekasi

\begin{tabular}{|c|c|c|}
\hline Gejala & Jumlah & Presentase \\
\hline Demam & 106 & 100 \\
\hline Mual & 26 & 24,5 \\
\hline Muntah & 11 & 10,4 \\
\hline $\begin{array}{c}\text { Nyeri ulu } \\
\text { hati }\end{array}$ & 15 & 14,2 \\
\hline Lemas & 45 & 42,5 \\
\hline Lidah kotor & 8 & 7,5 \\
\hline Diare & 30 & 28,3 \\
\hline
\end{tabular}

Sesuai dengan tabel diatas, gejala klinis yang paling banyak ditemukan dalam penelitian ini adalah demam dengan jumlah 106 pasien, diikuti dengan gejala lemas berjumlah 45 pasien, gangguan pada saluran pencernaan seperti mual 26 pasien, muntah 11 pasien, dan diare 30 pasien. Selain itu terdapat juga pasien dengan gejala coated tongue atau lidah kotor sebanyak 8 orang. Banyaknya gejala klinis yang ditemui dalam penelitian ini, sejalan dengan penelitian yang dilakukan oleh Saraswati, Junaidi, dan Ulfa mengenai karakteristik Tersangka Demam Tifoid di Rumah Sakit Muhammadiyah Palembang yang menyebutkan bahwa gejala klinis yang paling sering muncul adalah demam dan gangguan pencernaan. ${ }^{13}$ Selain itu, penelitian yang dilakukan oleh Muhammad Abrar Azhar juga menjelaskan bahwa gejala yang paling banyak ditemukan adalah demam. ${ }^{14}$ Dari hasil diatas, dapat diketahui bahwa gejala klinis demam tifoid sangat bervariasi. Gejala yang demam paling banyak ditemukan pada penelitian ini karena hampir semua pasien datang dengan keluhan utama yaitu demam.

Tabel 3. Distribusi pemakaian antibiotik

\begin{tabular}{|c|c|c|}
\hline Antibiotik & Frekuensi & Presentase \\
\hline Seftriakson & 95 & $89,6 \%$ \\
\hline Sefotaksim & 11 & $10,4 \%$ \\
\hline Jumlah & 106 & $100 \%$ \\
\hline
\end{tabular}

Hasil penelitian menyimpulan bahwa pasien demam tifoid rawat inap di RSUD periode Januari Desember 2019 berjumlah 106 pasien. Antibiotik yang digunakan adalah seftriakson dan sefotaksim. Antibiotik ini merupakan antibiotik yang paling sering digunakan dalam menangani demam tifoid dibandingakan dengan golongan antibiotik lainnya. Dengan jumlah pasien yang memakai injeksi seftriakson 95 pasien dengan 
presentase $89,6 \%$ sedangkan antibiotic sefotaksin 11 pasien dengan presentase $10,4 \%$. Seftriakson dan sefotaksim merupakan golongan sefalosporin ketiga yang kurang aktif dibandingkan dengan antibiotik generasi pertama terhadap kokus gram-positif. Tetapi jauh lebih efektif terhadap Enterobacteriaceae. ${ }^{15}$

Menurut penelitian yang dilakukan oleh Nia Kurniati mengatakan bahwa antibiotik seftriakson dan sefotaksim merupakan antibiotik yang paling banyak digunakan karena banyak laporan mengenai MDRST pada lini pertamanya. Selain itu, obat golongan ini mempunyai sifat yang menguntungkan bagi pasien karena dapat merusak struktur sel bakteri tanpa mengganggu sel manusia, spektrumnya luas, dan resistensinya terhadap bakteri masih terbatas. ${ }^{16}$

Dari tabel tersebut, dapat dilihat bahwa frekuensi pasien yang menggunakan seftriakson lebih banyak dibandingkan dengan sefotaksim. Hal ini dipengaruhi oleh waktu paruh antibiotik tersebut. Antibiotik seftriakson memiliki waktu paruh yang lebih lama yaitu 6-9 jam sedangkan sefotaksim hanya sekitar 1,4-1,9 jam. Selain itu seftriakson merupakan antibiotik golongan beta-lactamase yang berarti memiliki mekanisme kerja menghambat sintesis dinding sel bakteri dan memilii efetivitas tinggi terhadap gram negative. $^{17}$

\section{Tabel 4. Hubungan waktu bebas panas}

\begin{tabular}{|c|c|c|}
\hline Antibiotik & $\begin{array}{c}\text { Waktu bebas panas } \\
\text { (Rerata) }\end{array}$ & P \\
\hline Seftriakson & 13,95 & 0,06 \\
\hline Sefotaksim & 16,09 & \\
\hline
\end{tabular}

Respon terapi pada peneletian ini dapat dilihat dari waktu bebas panas dan lama perawatan. Waktu bebas panas merupakan salah satu parameter keberhasilan pengobatan karena suhu badan yang turun menandakan berhasilnya pengobatan. Jika suhu badan tidak turun, makan menandakan adanya infeksi lain atau bahkan kompikasi. Data yang didapatkan dari table diatas, dapat dilihat seftriakson memiliki rata-rata waktu bebas panas 13,95 jam sedangkan sefotaksim 16,09 jam. Sehingga dari tabel diatas, dapat disimpulkan bahwa antibiotik seftriakson memberikan waktu bebas panas lebih cepat dibandingkan dengan sefotaksim.

Berdasarkan tabel diatas dilakukan uji korelasi menggunakan uji Mann-Whitney $U$ didapatkan nilai koefisien sebesar 0,06 ( $\mathrm{p}<0,05)$. Dari uji tersebut dapat disimpulkan bahwa tidak terdapat perbedaan bermakna waktu bebas panas seftriakson dan sefotaksim. Hal ini sesuai dengan penelitian yang dilakukan oleh Risha Fillah Fith ria, Kiki Damayanti dan Risma Putri Fauziah dituliskan bahwa tidak terdapat perbedaan bermakna waktu bebas panas antara seftriakson dan sefotaksim. ${ }^{10}$

Tabel 5. Lama perawatan

\begin{tabular}{|c|c|c|}
\hline Antibiotik & Lama perawatan (hari) & P \\
\cline { 1 - 2 } Seftriakson & 4,16 & \multirow{2}{*}{0,062} \\
\hline Sefotaksim & 4,45 & \\
\hline
\end{tabular}

Berdasarkan tabel diatas dapat disimpulkan ratarata lama rawat inap pasien yang menggunakan seftriakson dan sefotaksim tidak terlalu jauh berbeda. Pada tabel diatas didapatkan rata-rata lama perawatan antibiotik seftriakson rata-rata 4,16 hari sedangkan 4,45 hari. Hal ini sesuai dengan penelitian yang dilakukan oleh Gina Hanu, Esy Nansy dan Ressi Susanti bahwa tidak terdapat perbedaan yang signifikan terhadap lama perawatan pasien demam tifoid yang menggunakan antibiotik seftriakson dan sefotaksim. ${ }^{17} \mathrm{Hal}$ ini dapat disebabkan karena jumlah sampel pasien yang menggunakan antibiotik seftriakson lebih banyak dibandikan dengan sefotaksim.dilakukan uji korelasi Mann Whitney $U$ didapatkan nilai koefisien sebesar 0,062 ( $\mathrm{p}<0,05$ ) yang berarti dari uji tersebut dapat disimpulkan bahwa tidak terdapat perbedaan bermakana terhadap lama perawatan pasien demam tifoid yang menggunakan seftriakson dan sefotaksim.

\section{KESIMPULAN}

Dari penelitian diatas, dapat disimpulkan bahwa kejadian demam tifoid lebih banyak pada laki-laki daripada perempuan terkait dengan kesadaran diri dalam menjaga higienitas. Selain itu, tidak dapat perbandingan bermakna anatara waktu bebas panas seftriakson dan sefotaksim

\section{DAFTAR PUSTAKA}

1.Fitriany J, Mauliza. Typhoid Fever Profiles at Cut Meutia Hospital, North Aceh, Indonesia, in 2016-2017. Emerald Reach Proceedings Series. 2017 ; 1 : 396.

2. Widodo W. Evaluasi Penggunaan Dan Efektifitas Pemberian Antibiotik Pada Pasien Demam Tifoid Di Instalasi Rawat Inap Rsud Sukoharjo Pada Periode 1 Oktober - 31 Desember 2015. Fakultas Farmasi Universitas Muhammadiyah Surakarta. 2016; 2. 
3. Alba S, Bakker MI, Hatta M, Scheelbeek PFD, Dwiyanti R, Usman R, et al. Risk Factors of Typhoid Infection in the Indonesian Archipelago. PLoS ONE. $2016 ; 11(6): 2$

4. Purba S. Nadapdap TP. Supeno H. Gambaran Penderita Demam Tifoid Pada Remaja Awal Yang Dirawat Inap Di Rumah Sakit Umum Daerah Deli Serdang Lubuk Pakam Tahun 2016. Jurnal Kedokteran Methodist. $2017 ; 10(1): 3$

5. Widagdo. Demam tifoid. Masalah dan tatalaksana penyakit infeksi pada anak. Sagung seto. 2011: 73

6. Saporito, L., Colomba, C., \& Titone, L. (2017). Typhoid Fever. International Encyclopedia of Public Health, 282-283. Diunduh dari doi:10.1016/b978-0-12-803678-5.00475-631 oktober 2019

7. Fithria RH. Damayanti K. Fauziah RP.Perbedaan efektivitas antibiotik pada terapi demam tifoid di puskesmas bancak kabupaten semarang tahun 2014. Fakultas Farmasi Universitas Wahid Hasyim Semarang. 2014 ;

8. Nainggolan S. Analisis Dokumen. Pengantar survey riset kesehatan masyarakat Ed 1. Penerbit Nusa Litera Inspirasi. $2018: 26-27$

9. Pramitasari OP. Faktor Risiko Kejadian Penyakit Demam Tifoid Pada Penderita yang Dirawat Di Rumah sakit Umum Daerah Unggaran. Jurnal Kesehatan Masyaralat Universitas Dipenegoro. 2013 ; 2(1) : 3 di Unduh dari https://media.neliti.com/media/publications/18787-IDfaktor-risiko-kejadian-penyakit-demam-tifoid-padapenderita-yang-dirawat-di-ruma.pdf

10. Fithria RF, Damayanti K, Fauziah R. Perbedaan Efektivitas Antibiotik Pada Terapi Demam Tifoid Di Puskesmas Bancak Kabupaten Semarang Tahun 2014. Fakultas Farmasi Universitas Wahid Hasyim . 201

\section{Rampengan NH. Antibiotik Terapi Demam Tifoid}

Tanpa Komplikasi pada anak. Sari Pediatri. 2013 ; 14(5)

$$
\text { : } 274 \quad \text { Di unduh dari }
$$

https://saripediatri.org/index.php/sari-

pediatri/article/view/325/266
12. Pramitasari OP. Faktor Risiko Kejadian Penyakit Demam Tifoid Pada Penderita yang Dirawat Di Rumah sakit Umum Daerah Unggaran. Jurnal Kesehatan Masyaralat Universitas Dipenegoro. 2013 ; 2(1) : 6 di Unduh dari https://media.neliti.com/media/publications/18787-IDfaktor-risiko-kejadian-penyakit-demam-tifoid-padapenderita-yang-dirawat-di-ruma.pdf

13. Saraswati N, Junaidi AR, Ulfa M. Karakteristik Tersangka Demam Tifoid Pasien Rawat Inap di Rumah Sakit Muhammadiyah Palembang Periode Tahun 2010. Syifa'MEDIKA, $2012 ; 3(1): 3$

14. Azhar Ma. Perbandingan Uji Tubex Dengan Widal Terhadap Gejala Klinis Pada Demam Tifoid Deasa Di Rumah Sakit Umum Daerah DR. Zainoel Abidin Banda Aceh. Universitas Syiah Kuala. 2014 : 51

15. Oktaviani E. Analisi Efektivitas Biaya Penggunaan Injeksi Seftriakson dan Sefotaksim Pada Pasien Demam Tifoid Di Instalasi Rawat Inap Rumah Sakit Umum Daerah ambarawa Tahun 2016. Fakultas Farmasi Universitas Setia Budi. 2017 ; 42-43 Di unduh dari http://repository.setiabudi.ac.id/1012/2/SKRIPSI\%20p ost\%20ujian\%202.pdf

16. Kurniati N. Kesesuaian Pemberian Antibiotik Demam Tifoid Pada Anak Di Unit Rawat Inap Rumah Sakit Umum Aminah Blitar Tahun 2017. Akademi Farmasi Putra Indonesia Malang. 2018 : 7-9 di unduh dari

http://repository.pimedu.ac.id/id/eprint/250/1/artikel\%2 0jurnal\%20fix.pdf

17. Rizka GH, Nansy E, Susanti R. Analisis Efektivitas Seftriakson dan Sefotaksim pada Pasien Rawat Inap Demam Tifoid Anak di RSUD Sultan Syarif Mohamad Alkadrie Kota Pontianak. 2016 ; 5 Di unduh dari https://pdfs.semanticscholar.org/e878/f077524c07877a db50388c6f918fcf24c216.pdf? ga=2.180652836.2082 $\underline{564285.1591106525-1735093715.1591106525}$ 